Kaygı, 31/2018: 239-261.

Araştırma Makalesi | Research Article

Makale Geliş | Received: 04.07.2018

Makale Kabul | Accepted: 25.09.2018

Yayın Tarihi | Publication Date: 30.10 .2018

DOI: $10.20981 /$ kaygi.479374

Celal YEŞiLÇAYIR

Dr. Öğr. Üyesi | Assist. Prof. Dr. Gümüşhane Üniversitesi, Edebiyat Fakültesi, Felsefe Bölümü, Gümüşhane, TR Gümüşhane University, Faculty of Letters, Department of Philosophy, Gümüşhane, TR ORCID: 0000-0002-3132-920X

cyesilcayir@gumushane.edu.tr

\title{
İnsan Haklarının Aydınlatılmasında Felsefi Bilginin Önemi
}

\section{$\ddot{O ̈ z}$}

İnsan hakları belirgin, somut olanı değil, soyut ve düşünsel olanı ifade eden bir kavramdır. Soyut ve düşünsel içeriğinden dolayı insan haklarının özü itibariyle anlaş̧labilmesi temel bir sorunsal olarak karşımıza çıkmaktadır. Söz konusu sorunsala istinaden bu çalışma insan haklarının aydınlatılmasında felsefi bilginin yeri ve önemini tartışmayı amaçlamaktadır. Bu çerçevede temel olarak felsefenin etik, epistemoloji ve hukuk felsefesi gibi disiplinlerinin insan haklarının aydınlatılmasında hangi rolleri oynayabileceği analiz edilmektedir. Diğer taraftan felsefenin eleştirel, sorgulayıcı ve sorunların özüne nüfuz edici karakterinin insan hakları konusunda bilgisel aydınlanma sağlayıcı mahiyette olup olmadığı irdelenmektedir. Ayrıca felsefi bilginin insan hakları konusunda verilecek eğitimdeki rolü ve hakların bilincine varmak hususunda hangi argümanları sağlayabileceği üzerinde durulmaktadır. Araştırmamız çerçevesinde hakkın hukuka, doğal hukukun da pozitif hukuka göre önceliği ve yetkinliği insan haklarının felsefi bağlamda aydınlatılmasında başat rol oynamaktadır.

Anahtar Kelimeler: İnsan Hakları, İnsan Onuru, Etik, Hukuk, Epistemoloji.

\section{The Significance of Philosophical Knowledge in Enlightening of the Human Rights}

\begin{abstract}
Human rights is a concept which expresses the abstract and ideation rather than apparent and concrete. It is a basic problematic to comprehend human rights in essence due to its abstract and ideational content. Due to this problematic, this research study aims to discuss the place and significance of philosophical information in enlightening the human rights. In this framework, exactly what roles do the disciplines of philosophy such as ethics, epistemology, and law philosophy have on enlightening the human rights are analyzed. On the other hand, it is investigated whether the critical, interrogator and problem-penetrating characteristics of philosophy supports informative enlightening of human rights. Moreover, it is discoursed, which arguments philosophy provides to comprehend the rights, and the role of the philosophical information in human rights education. In the framework of this research study, the competence and priority of right over law, and natural law over positive law play a leading role in enlightening human rights in philosophical context.
\end{abstract}

Keywords: Human Rights, Human Dignity, Ethics, Law, Epistemology 


\section{Giriş}

İnsan haklarını korumaya yönelik uluslararası anlamda resmi belgelerin hazırlanmasını ve bu belgelerin uluslararası kamuoyuna ilan edilmesini insanlık adına önemli bir gelişme olarak nitelendirmek mümkündür. Bu belgelerin en önemlilerinden biri olan ve "Bütün insanlar, özgür, onur ve haklar bakımından eşit doğar" maddesiyle başlayan İnsan Hakları Evrensel Bildirgesi (İHEB) 1948'de ilan edilmiştir. Ancak söz konusu deklarasyonun ilanından sonra da küresel anlamda insan hakları ihlalleri önceden olduğu gibi devam etmiştir. 1992-1995 arası Bosna ve Srebrenitsa'da yaşanan soykırımlar yakın tarihte yaşanan insan hakları ihlalinin en bariz örneğidir. Bununla birlikte küresel adalet ve barışı sağlamak üzere kurulmuş olan Birleşmiş Milletlerin daimi üyelerinin insan hakları hususunda çok masum oldukları söylenemez. Bunun en çarpıcı örneklerinden birisi Darfur (Sudan) meselesi sırasında gün yüzüne çıkmıştır. Bölgede 2003 yılında başlayan iç savaşta yaşananlar, 2004 yılında BM'nin gönderdiği heyet tarafindan katliam olarak rapor edilmiştir (Gerlach 2010: 61-62). Ancak Rusya ve Çin'in Sudan'a el altından silah ve petrol sattıkları ortaya çıkmıştır (Schmeer 2010: 95). Felsefi eleştirellik/sorgulayıcılık bağlamında düşünüldüğünde; İHEB'in ilanına rağmen hak ihlallerinin devam etmesini tam anlamıla bir paradoks olarak nitelendirmek yerinde bir tutum olacaktır.

Öyle ki dünya kamuoyunda bir taraftan insan hakları söylemleri artarken, diğer taraftan da insan hakları ihlallerinin devam ettiği gözlenmektedir (DW 2008). Bu noktada insan hakları hususunda yaşanan mezkûr sorunları neden felsefi bir mesele olarak gördügümüzü izah etmeye çalışalım: Felsefe mahiyeti gereği insana ait olan kadim sorunları temellerine inerek anlama çabası içinde olan bir disiplindir. Dolayısıyla insan hakları gibi temel insani bir konuda küresel çapta yaşanan sorunlar karşısında felsefenin/felsefecinin kayıtsız kalması beklenemez. Söz konusu sorunsala istinaden bu makalede insan haklarının temellerinin aydınlatılmasında felsefi bilginin öneminin tartışılması amaçlamaktadır. İnsan hakları ifadesinden neyi anlamamız gerektiğine ve bu 
çerçevede bizim neyi tartışmayı amaçladığımıza değinerek araştırmamıza girişmemiz yerinde bir tutum olacaktır.

İnsan hakları, siyasal, toplumsal ve hukuki alanlardaki geniş kullanımının yanında, çokça başvurulan, sıklıkla atıf yapılan, insan hayatı ile doğrudan ilişkili olan bir kavramdır. Söz konusu haklar genel olarak insanın birey olmaktan kaynaklanan haklarına işaret etmektedir. Ancak insan hakları kavramı, sözgelimi kalem gibi, tek bir nesneye işaret etmez. Tekil/somut bir karşılı̆̆ı yoktur. Ayrıca insan haklarının bir üçgenin iç açılarını toplamak gibi matematiksel bir problem ya da laboratuvar ortamında kanıtlanabilir bilimsel bir olgu olmaktan çok farklı bir sorunsal olduğunu da belirtmemiz gerekmektedir. Şu halde insan hakları, salt insan olmaktan kaynaklanan haklara işaret ettiğinden soyut ve düşünsel bir kavram olarak ele alınmalıdır. Öyle ki insana ait kadim olanı kavram ve kavramlar arası ilişkiler çerçevesinde anlamaya çalışan felsefenin insan haklarının anlaşılmasında ileri sürebileceği argümanlar olmalıdır. Bununla birlikte insan haklarının doğru bir biçimde anlaşılması haklar konusunda yaşanan/yaşanabilecek kavram kargaşası ve bilgi kirliliği gibi sorunları önlemek adına da önemli bir adım olacaktır. Dolayısıyla insan haklarının temellerinin ve muhtevasının bilgisel olarak aydınlatılmasının önemli bir gereksinim olduğu anlaşılmaktadır.

Söz konusu bilgisel aydınlanmanın felsefi bağlamda ele alınabilmesi için öncelikle insan hakları ile felsefe arasındaki ilişkinin anlaşılması gerekmektedir. Araştırmamız çerçevesinde öncelikle insan haklarının bilgisinden ne anlaşılması gerektiği ele alınacaktır. İkinci adımda insan hakları ve felsefi bilgi ilişkisi sorgulanarak, söz konusu haklar ile felsefe arasındaki ilişkinin mahiyeti tartışılacaktır. $\mathrm{Bu}$ çerçevede insan haklarını felsefe açısından irdelemek bakımından felsefenin başlıca disiplinlerinden etik, hukuk felsefesi ve epistemoloji bağlamında insan hakları sorunsalı analiz edilmeye çalışılacaktır. Ayrıca insan hakları ihlalleri karşısında felsefenin nasıl bir duruş sergilemesi gerektiği sorgulanacaktır. Son tahlilde ise yapılan analizler üzerinden insan hakları bilincinin gelişmesi adına felsefi bilgiden nasıl yararlanılabileceği hususunda bazı tespitlere ulaşılması amaçlanmaktadır. 
Konumuzu tartışmaya geçmeden önce insan hakları ifadesini kullanıldığı anlam genişliği içinden hangi bağlamlarda ele alıp tartışacağımıza kısaca değinmek yerinde bir tutum olacaktır. Hakkın varlığını hukuk düzenine bağlı ele alan görüşler, daha çok pozitif hukuk ya da devletçi pozitivizm olarak adlandırılmaktadır. Böyle bir anlayışta devletin koyduğu ve devletin varlığına razı olduğu kurallar hukuk olarak kabul edilmektedir (Keyman 1998: 17). İnsan hakları özünde evrenselliği barındıran bir kavram olarak pozitif hukukun ötesinde/üstünde haklardır. Buna göre insan hakları insanın salt insan olması ile ilgili haklara tekabül ettiğinden kaynağını doğal hukukta bulmaktadır. Doğal hukuk ise, pozitif hukuktan farklı olarak, herhangi bir araca ve özellikle hiç bir normatif olguya başvurulmaksızın insanın kadim haklarına işaret etmektedir. Bu yönüyle doğal hukuk, kökleri insan doğası ve insan aklına dayanan, pozitif hukukun sınırlayıcılığa karşın, içinde evrenselliği barındıran haklardır (Keyman 1998: 18). Çünkü doğal hukuk, insanlar üzerinde, bütün anlaşmalar ve pozitif hukuk sistemlerinden bağımsız olarak, salt insani doğalarından dolayı bağlayıcılı̆̆ı olan haklara işaret etmektedirler (Cevizci 2014/b: 132, 133). Diğer bir ifadeyle doğal hukuku, ülke anayasalarındaki haklarla sınırlı olmayan, bütün insanlar için aynı değeri içeren evrensel hakların temsili olarak nitelendirmek mümkündür. Sözgelimi yaşama hakkı, eşit yurttaşlık hakkı ve eğitim alma hakkı bu türden haklardır. Dolayısıyla insan hakları belli bir anayasa ya da hukuk maddesine sığdırılamayacak derecede insanın kadim haklarına işaret etmektedir. Ancak insan haklarının ileri sürdüğümüz söz konusu boyutunun ve bu haklarla felsefe arasındaki ilişkinin aydınlatılması için teorik, kavramsal, bilgisel temelli analizler gerekmektedir. Bu çerçevede söz konusu analize insan haklarının bilgisinin ne anlama geldiğini tartışarak başlamamız yerinde olacaktır.

\section{İnsan Haklarının Bilgisi Nedir?}

İnsanlık durumlarına bakıldığında insan hakları bildirgelerine rağmen küresel anlamda hak ihlallerinin devam ettiği görülmektedir. Öyle ki savaş, tecrit ve tehdit gibi insan hayatını doğrudan etkileyen olumsuz şartlar nedeniyle birçok insan doğup büyüdüğü yeri terk etmek zorunda kalmaktadır. Akdeniz'de alabora olan sığınmacı 
tekneleri ve kıyılara vuran cesetler zihnimizde canlılığını sürekli korumaktadır (Yeşilçayır 2016: 122). Bugünlerde Almanya’nın sınır dışı ettiği Afgan bir sığınmacının intihar etmesi (Sirleschtov, Monath, Woratschka, 2018) üzerine insan hakları bağlamında yaşama hakkı konusu uluslararası kamuoyunda tartışılmaktadır. Aslında bu tartışmayı genişleterek evrensel bildirgelere rağmen insan hakları ihlallerinin niçin önlemediğinin irdelenmesi gerekmektedir. Şu halde araştırmamız çerçevesinde insan haklarının bilgisine ulaşmak ihlalleri önlemek için yeterli midir? sorusuna da analiz etmeye ve son tahlilde cevaplandırmaya çalışalım.

Görebildiğimiz kadarıyla insan haklarının doğru ve tutarlı bir biçimde uygulamaya geçirilememesinin en önemli nedeni bilgisel bir sorundur. İnsan hakları ve bilgi ilişkisi bağlamında ciddi anlamda eksikliğin/yanlışlığın yanı sıra hangi bilgiye nasıl ulaşılacağı hususunda da ciddi açmazların yaşandığı dikkatlerden kaçmamaktadır. Küresel anlamda yaşanan insan hakları ihlalleri ve insan haklarını korumaya yönelik dünya siyasetinin elinde hâlihazırda bir planın olmaması insan hakları konusunda yaşanan bilgi sorununun bir göstergesidir. İnsan hakları ile ilgili kaynaklarda yer alan yaygın anlayışa göre insan hakları bireylerin yalnızca insan olmalarından kaynaklanan haklardır ve insan olmak bu haklara sahip olmak için yeterlidir. Buna göre 1rk, din, milliyet, cinsiyet, ekonomik veya sosyal statü ayrımı gözetmeksizin, insan onurunun gereği olarak bütün kişilerin sahip olduğu vazgeçilmez/devredilmez hakların tümüne insan hakları denir (Tezcan, Erdem, Sancaktar, Önok: 2011 35). Söz konusu hakların kavramsal içeriğinin zikredilen insan onuru bağlamında aydınlatılması için bilginin vazgeçilmez bir öneme sahip olduğu aşikârdır. Buna göre insan haklarına ilişkin bilincin istenilen seviyede olmamasının temel nedeni insan hakları konusundaki bilgi seviyesinin ve bu bilgiyi kazandıracak eğitimin oldukça yetersiz olmasıdır. Dolayısıyla bireylerde insan hakları bilincinin oluşabilmesi için bilgi ve eğitim yadsınamaz bir öneme sahiptir. Buna göre temel birey hakları olan insan haklarını kavrayabilmek için öncelikle söz konusu hakların temellerinin ve mahiyetinin anlaşılması gerekmektedir. İnsan haklarının aydınlatılması hususunda değişik bilgi türlerinden söz etmek mümkündür: Örneğin tarihi bilgi ve siyasal bilgi bunlardan ikisidir. Tarihi bilgi, insan 
hakları belgelerinin tarihte ortaya çıkışı ve gelişimi hakkında bilgi sahibi olmak için önem arz etmektedir. Siyasal bilgi ise insan haklarının siyaset sahnesinde yer etmesi ve siyasi anlamda insan haklarının anlamı konusunda başvurulacak kaynaktır. Bununla birlikte insan hakları belgelerinin tarihsel anlamda aydınlatılması ve siyasi anlamda değerlendirilmesi konunun anlaşılması bakımından yeterli değil midir? ve insan hakları bağlamında felsefi bilginin rolü nedir? gibi sorular karşımıza çıkmaktadır.

Kuçuradi'ye göre haklarla ilgili belgelerde zaman zaman temel kişi hakları grup haklarıyla karıştırılabilmektedir (Kuçuradi 2016: 196). Dolayısıyla bu belgelerde yer alan kavramsal karışıklıkların sorgulanıp, giderilmesinde felsefi bilgiye ihtiyaç duyulduğu anlaşılmaktadır. Söz konusu yanıltıcı tutumların bertaraf edilmesi hususunda da felsefenin eleştirel ve sorgulayıcı özelliğine başvurulması gerekmektedir. Bu araştırma esnasında insan haklarının felsefe bağlamında aydınlatılmasında başlıca şu hususlar üzerinde durulacaktır: 1) Felsefe tarihinde insan hakları düşüncesinin ortaya çıkış1 2) Felsefi etik bağlamında, 3) hukuk felsefesi bağlamında, 4) epistemoloji bağlamının insan haklarının ele alınması. 5) Felsefenin eleştirel/sorgulayıcı özelliği ile insan haklarını sorgulamaya çalışmak. Belirlediğimiz hususları, öncelikle insan hakları ve felsefe ilişkisini sorgulayarak, analiz etmeye çalışalım.

\section{İnsan Hakları ve Felsefi Bilgi İlişsisi}

İnsan hakları ve felsefi bilgi ilişkisinin anlaşılmasında felsefenin temel karakteristiği bağlamında söz konusu hakların kaynağı ve mahiyetinin analiz edilmesi gerekmektedir. Eğer insan haklarını kişinin yalnızca insan olmasından kaynaklanan hakları olarak tanımlıyorsak pozitif hukukun sınırlı hak anlayışının insan haklarına kaynaklık etmesi pek doğru bir tutum olmayacaktır. Bu durumda insan haklarının temellerini insanın salt insan olmasından kaynaklanan doğal hukuk anlayışı çerçevesinde ele almak gerekmektedir. Yukarda insan haklarının doğal hukuk ve pozitif hukukla olan ilişkisine değinmeye çalıştık. 
Bununla birlikte insan haklarının temelinde doğal hukukun yer aldığının ortaya çıkması insan haklarının analiz edilmesine ilişkin başka kavramlara da işaret etmektedir. Çünkü doğal hukukun özüne inildiğinde insanın değeri ve insan onuru ile karşılaşılmaktadır. İnsan hakları, yaşamak hakkından başlamak üzere, insanların doğası gereği sahip olduğu insan onuruna dayanır (Öğütçü 2005: 569) ve insan haklarını üzerinde yükseldiği bu temellerden bağımsız düşünmek mümkün değildir. Birçok düşünür insan haklarının temelinde insan onurunun olduğu konusunda hemfikirdir. Söz gelimi Charles Beitzt insan hayatı için son derece önemli olan insan haklarının kaynağını oluşturan insan onurunun anlaşılmasının söz konusu temel hakların aydınlatılması adına önemli bir adım olacağı kanaatindedir (Beitzt 2013: 260). Jürgen Habermas ise insan onuru ifadesinin aydınlatılması konusunda filozofların düşüncelerine dikkat çekmeye çalışarak, insan onurunun özü itibariyle felsefi bir kavram olduğunu ve ortaya çıkışının Antik döneme kadar geri gitmekle birlikte modern anlamdaki kavramsal çerçevesini Kant'la birlikte kazandığını iddia etmektedir (Habermas 2010: 344). Tarihsel bakımdan insan onuru kavramının insan hakları belgelerinde ilk olarak II. Dünya Savaşından sonra yer almaya başladığı görülmektedir. Buna göre insan haklarını ve bu kavramın özünü oluşturan insan onurunu anlamak için yalnızca insan hakları belgelerine başvurmak konuyu oldukça dar bir çerçevede değerlendirmek anlamına gelecektir. Çünkü felsefe tarihi incelendiğinde insan onurunun XX. yüzyılda ortaya çıkmış bir kavram olmadığı, temellerinin Antikçağ'da atıldığ1 ortaya çıkmaktadır.

İnsan hakları kavramının düşünsel temellerinin felsefe tarihinde nasıl ele alındığı ile ilgili kısa bir yolculuğa çıkabiliriz: Felsefenin özellikle insana yönelmesiyle birlikte insan eylemi ile erdem arasında bir ilişki kurulamaya başlanmıştır. İnsan felsefesinin önemli filozoflarından olan Sokrates Antikçağ Atina'sında ahlaki değerlerin yozlaşmaya başlaması üzerine ortaya attığı erdem etiği anlayışı ile günümüzde etiğin kurucusu olarak kabul edilmektedir (Cevizci 2014/a: 138). Onun onurlu bir hayatın temellerini sorgulayan, en yüksek iyiyi ve adaleti amaçlayan bu anlayışı sonraları Platon ve Aristoteles tarafından geliştirilmiştir. 
Helenistik dönemde yaşayan Stoacılar ise hümanist bir bakış açısıyla insanları, dünya toplumunun eşit yurttaşları olarak görüyorlardı. Daha çok erdem temelli bir eşit insan anlayışı ortaya koymaya çalışan Stoacılar bu durumun insanlar tarafından idrak edilmesi için felsefelerini icra etmeye çalışıyorlardı. Birbirlerine karşı herhangi bir üstünlüğü olmayan insanların birbirlerine karşı saygılı ve toleranslı olmalarını öneriyorlardı (Manstetten 2005: 109, Yeşilçayır, 2017: 100, 101). Stoacılardan yaklaşık 2000 yıl sonra bu düşünceleri tekrar ele alan Kant, onların temelini attığı hümanizm ve evrensellikle ilgili düşüncelere kendi döneminin koşulları içinde sistematik bir çerçeve çizmeye çalışacaktır. Kant'ın düşüncelerinin yanında Grotius ve Locke'un hak/haklar kavramı üzerindeki düşünceleri ile Rousseau'nun yurttaşların genel iradesinden söz etmesi 1789'da ilan edilecek olan Insan ve Yurttaş Hakları Bildirisinde doğal haklar, kutsal ve vazgeçilmez haklar olarak maddeleşmiştir (Çotuksöken 2012: 28). Bununla birlikte bu gelenek içinde, Michael Sandel'in de üzerinde durduğu gibi, özgürlüğü adalet ve ahlakla temellendirmesi ve insan saygıyı temele almasından dolayı Kant günümüz evrensel insan hakları düşüncesinin habercisidir (Sandel 2013: 130). Düşünce tarihindeki bu kısa yolculuktan sonra günümüzde modern çerçevesi ve kalıplarıyla bilinen insan haklarının ne olduğunun ve mahiyetinin aydınlatılması açısından temellerinin irdelenmesine geçebiliriz.

Görebildiğimiz kadarıyla insan hakları öncelikle felsefenin ana disiplininden biri olan etik çerçevesinde aydınlatılması gereken bir kavram olarak belirmektedir. Bununla birlikte insan haklarının (düşünsel) temellerinin etik bir sorunsal olduğunun ortaya konulması için epistemolojik sorgulamaların elzem olduğu görülmektedir. Diğer bir ifadeyle soyut insan hakları düşüncesinin sözel ve davranışsal edimler yoluyla görünürlük kazanması için bilginin vazgeçilmez bir önemi söz konusudur (Davran 1999: 19). Bu noktada felsefi bilginin insan haklarının soyut ve düşünsel boyutunu temellendirmek için önemli bir rol oynayabileceğini iddia etmemiz mümkündür. Diğer taraftan insan haklarının aydınlatılmasında etik ve epistemoloji gibi temel alanların yanında insan hakları ile hukuk arasındaki ilişkinin görmezden gelinmesi mümkün değildir. Bu bağlamda felsefenin diğer bir disiplini olan hukuk felsefesi başvurulması 
gereken temel bir mecra olarak belirmektedir. Ancak insan haklarının etik temelleri ile hukuki boyutu arasındaki rabıtayı kurgulamanın yine bir epistemolojik sorunsal olduğunun altını çizmemiz gerekmektedir. Bu noktada insan hakları ve felsefi bilgi ilişkisini felsefenin temel disiplinleri bağlamında üç aşamalı olarak ele alıp, analiz etmeye çalışalım.

\section{İnsan Haklarının Etik Temelleri}

İnsan hakları bağlamında her bireyin salt toplumsal, kültürel ve yerel değerlere değil, aynı zamanda etik değerlere sahip bir varlık olduğu konusunda bilgi sahibi olması önem arz etmektedir. Çünkü insan hakları ile ilgili bilgi temelde evrensel olana işaret etmektedir (Çotuksöken 2012: 35). Bu noktada ahlak ve etik arasında farka kısaca değinmemiz yerinde olabilir: Ahlak normlar bakımından toplumsal, bölgesel ve lokal olarak farklılık arz edebilirken, etiği evrensel ahlak normları olarak açıklamak gerekmektedir. Bunun yanında ahlak pratik insan davranışını konu edinirken, etik ahlakın teorisi olmak durumundadır(Cevizci 2014(1): 17, 18). İnsan olmak, etnik köken, ten rengi, cinsiyet, din ve mezhep gibi sıfatlardan önce gelen ve insanlığın ortak bir paydası olan bir özellik olarak evrensel bir temele dayanmaktadır. Dolayısıyla insan bütün diğer özellikleri öne çıkarılmaksızın, salt insan olarak düşünülmesi gereken bir varlıktır. O halde insan haklarının etik temellerini nasıl açıklamamız gerekmektedir?

Amartya Sen'e göre insan hakları yasal ve hukuki düzenlemelere konu olmadan önce birincil olarak etik (primarily ethical) bir temele dayanmaktadır (Sen 2004: 328332). Sen'in hak ve hukuk ilişkisi bağlamındaki düşüncesi de dikkate değerdir. Ona göre hakkın hukukun çocuğu olduğunu zikretmek doğru bir yaklaşım değildir, bilakis hakkın hukukun ebeveyni olduğunu vurgulamamız gerekmektedir (Sen 2004: 327). Bu durumda hakların etik temelleri söz konusu hakların yasalaşmasına da ilham kaynağ olabilecek mahiyettedir ve bu noktada önemli olan nokta ise hakların etik kökeninden koparılmadan yasalaşmasına (hukuk) önem verilmesidir. Sonraki bölümde insan hakları 
ve hukuk ilişkisini tartışmaya devam edeceğiz. Bu noktada öncelikle insan haklarının üzerinde yükseldiği etik temelinin mahiyetini tahlil etmemiz gerekmektedir.

İnsan haklarının etik temelleri bağlamında insan onuru ile insan hakları arasındaki vazgeçilmez ilişkinin aydınlatılması önem arz etmektedir. Buna göre insanın onuru, onun akıl ve vicdan sahibi bir varlık olması ile ilgilidir, diğer bir ifadeyle insan onuru insanın değerinin farkına varılması ile anlaşılabilecek bir durumdur. Akıl ve vicdan melekeleriyle insan diğer canlılar arasında özel yere sahiptir. Buna göre insan sadece biyolojik olarak değil aynı zamanda moral bir değer olarak var olan bir canlıdır. Bizatihi bir değer olan insanın, onuruna layık olarak yaşayıp, gelişmesi önemlidir ve hiçbir güç tarafından onun değeri/onuru ihlale uğramamalıdır (Savcı 2016: 87). Konu ile ilgili literatürde insan onurunun kaynağ1 olarak akıl ve vicdan sahibi olmaya işaret edilmektedir. Salt insan olmanın temel bir özelliği olan insan onuru evrensel bir değer olarak etik ile sıkı bir ilişki içindedir. Buna göre insan onurunun bir değer olarak anlaşı1ması, onun onuruna saygı duyulması ve korunması etik bir anlayışla mümkündür. Diğer bir ifadeyle insan onuru etik bir değere işaret etmektedir ve etik değerlere özen göstermek aynı zamanda insan onuruna da özen göstermek anlamına gelmektedir (Kuçuradi 2003: 9). Ak1l sahibi olmayı onurlu varlık olarak nitelendiren Kant'a göre kişinin eylemlerinde kendini ve başkalarını araç olarak değil, amaç olarak görmesi onurlu bir davranıştır. Buna göre onur sahibi bir varlık olarak insanı araç olarak değil, kendi başına bir amaç olarak görmek gerekmektedir. Bu tutum bize kimliği ne olursa olsun herkesi öncelikle insan olarak görmemiz adına önemli bir fikir sunmaktadır (Kılıç 2015: 98).

İnsanın söz konusu değerinin ve bu değer karşıllı̆ varılabilmesi için öncelikle insan olmanın bilincinde olunması gerekmektedir. Bununla birlikte insan onuru, değişik kültürlerdeki farklı insan imgelerinden ayrıştırılarak, insanın nesnel değerinin bir karşılığı olarak anlaşılmalıdır. Buradan hareketle insan haklarının insan onurunun pratikte gerektirdikleri evrensel normlar olduğunu ifade etmemiz mümkündür. Dolayısıyla insan onurunun bilgisi insan hakları normlarının oluşumunda belirleyicidir ve bu anlamda ele alındığında insan haklarını kültürel 
normlardan ayırarak evrensel etik normlar olarak nitelendirmemiz yerinde bir tutum olacaktır (Kuçuradi 2016: 70-76). Bununla birlikte her ne kadar insan haklarına herkesin insan olmasından kaynaklanan haklar olduğuna inanıyor ve bunu ifade ediyor olsak da, bu hakların ve temelini oluşturan etik değerin bilgisini sağlıklı bir biçimde edinmek gerekmektedir. Ancak böylelikle farklı kültür ve dinlerin insan imgesinden ayrışarak, etik temelli evrensel insan haklarının anlaşılması ve bu konudaki bilincin yaygınlaşmasını sağlanabilecektir.

Bununla birlikte insan haklarının etik temelleri ve insan onuru ile vazgeçilmez ilişkisi dikkate alınmadığında, bu haklar yalnızca bazı belge ya da hukuk maddelerinin sınırlı bağlamında değerlendirilecektir. Dolayısıyla insan haklarının etik temellerinin bilgisi, bu hakların evrensel, devredilemez ve vazgeçilmez karakterinin anlaşılması bakımından önem arz etmektedir. Şu halde insan olarak devredilmez onur ve hak sahibi olmak doğuştan getirilen bir özellik olmasına rağmen bunların bilgisi doğuştan verili değildir. İnsan haklarının temellerinde etik değerleri ve insan onurunun yer aldığının bilinmesi/öğrenilmesi çaba ve süreç gerektirmektedir. Etiğin insan haklarının temelini teşkil eden evrensel bir değer olduğunun altını çizmeye çalıştıktan sonra yukarda kısaca değinmeye çalıştığımız hukuk konusunu tartışmaya geçmemiz isabetli olacaktır. Bu bağlamda Sen'in hakkın hukukun üstünde (ebeveyni) olması gerektiği savından hareketle, insan haklarının yasalaşmasının niçin etik temellere dayanması gerektiğini de analiz etmeye çalışalım.

\section{İnsan Hakları ve Hukuk İlişkisi}

İnsan haklarının etik temellerini analiz ettikten sonra bu hakların göz ardı edilemeyecek olan hukuk alanı ile ilişskisini tartışmaya geçebiliriz. Bununla birlikte temel hakların etik temellerinden bağımsız bir insan hakları-hukuk ilişkisi ortaya koymaya çabası şüphesiz eksik bir analiz olacaktır. Etik ile hukukun varoluşsal ilişkisi ve insan haklarının hukuksal bağlamı hukuk felsefesinin konu edindiği temel meseleler arasındadır. Buna göre toplumsal yaşam düzeninin normlarını ahlak ve hukuk 
oluştururken, birincisi yazılı olmayan normları, ikincisi ise yazılı, yasalaşmış kuralları içermektedir. Ancak ahlak ile hukuk arasında, sözlü normların yazıya dönüşmesinin ötesinde, daha derin bir bağ olduğunu ifade etmemiz gerekmektedir. Buna göre etiğe karşılık gelen ve evrensel anlamda insan olma özüne işaret eden doğal hukuk teorisi, ahlak-hukuk ilişkisinde hayati bir öneme sahiptir. Doğal hukukun pozitif hukukun oluşumunda hangi oranda etkili olduğu sorunsalı aslında insan hakları-hukuk ilişkisini anlamamıza 1ş1k tutacaktır. Bununla birlikte doğal hukuk-pozitif hukuk ya da etikhukuk ilişkisi bağlamında insan haklarını nasıl açıklamalıyız? diye bir soru akıllara gelmektedir.

Yukarda hukuktan doğal hukuk ve pozitif hukuk diye iki ayrı kategoride söz etmeye çalıştık. Bu minvalde etik değerleri ihtiva eden doğal hukuk, evrensel anlamda tüm zamanlar için geçerli temel hakları ihtiva etmektedir. Pozitif hukuka göre insan hakları, belli bir zamanda, belli bir yerde; yürürlükte olan hukuk sitemi tarafından yazılı olarak oluşturulmuş haklardır (Öğütçü, 2005: 578). Felsefi bağlamda pozitif hukukun ideal biçiminin doğal hukuk içinde yer aldığını söylememiz mümkündür. Öğütçü insan haklarının sadece doğal hukuk kaynaklı bir kavram olmaktan çıkıp pozitif hukukla bütünleşerek ulusal ve uluslararası hukuk belgelerinde somut haklar haline dönüştüğünü iddia etmektedir (Öğütçü, 2005: 579). Ancak bu iddiaya şöyle bir eleştiri/soru yöneltmek mümkündür: Eğer doğal haklar gerçek anlamda pozitif haklara dönüşmüş olsaydı, insan hakları ihlallerinin tedricen azalması gerekmez miydi? Kanaatimize göre yaşanan hak ihlallerinde insan haklarının ideal biçimi olan doğal hukukun pozitif hukuklara yeterince yansımaması önemli bir rol oynamaktadır. Dolayısıyla insan haklarının sağlanması bakımından pozitif hukukun doğal hukukun etik temellerini örnek alması gerekmektedir.

Buna göre bir devletin insan haklarına dayalı olduğunu iddia edebilmek için hukukun oluşumunda, doğal hukukun örnek alınması gerekmektedir. Ancak insanın değerine dayalı bir hukuk dizgesi insan haklarının tanınması, korunması ve geliştirilmesi için uygun bir zemin olacaktır. Hukuk sistemlerinin oluşumunda insanın değeri ve onuru temele alınmadığı takdirde insan haklarının yasalarla korunması artık 
tesadüfe kalmış olacaktır. Dünyanın neresinde yaşarsa yaşasın burada temel olan insandır ve onun araç değil, amaç haline geldiği bir anlayışın benimsenmesi gerekmektedir. Bu anlayış bize aynı zamanda ulusal üstü hukuk kavramının kapısını da aralamaktadır. Dolayısıyla etik temelli hukuk, etnik ve kültür kaynaklı yasaların ötesinde ulusal üstü bir tutum çerçevesinde insana yönelen yasaları ihtiva etmelidir. Bu açıdan bakıldığında insan haklarının felsefesini yapmak bir bakıma hukukun içeriğinin etik ilkelerden oluşup oluşmadığının sorgulanması anlamına gelmektedir.

\section{İnsan Haklarının Epistemolojik Temellendirilmesi}

İnsan hakları her ne kadar insanın doğuştan getirdiği temel haklar olsalar da, bu hakların aydınlatılmasında bilginin vazgeçilmez bir öneme sahip olduğu anlaşılmaktadır. Çünkü doğuştan gelen ve kendiliğinden sahip olunan haklar, bilinmedikleri sürece yok hükmündedirler. Mesut Gülmez'in ifadesiyle insan ancak bildiği ve kullandığı haklarıyla vardır (Gülmez 2001: 49). İnsan hakları hususunda elzem olduğu anlaşılan bilmek eylemi ise epistemolojinin önemine işaret etmektedir. İnsan haklarının etik temellerinin ve hukuki boyutunun sorgulanıp, anlaşılmasında başat rol oynayan epistemolojinin kendine özgü karakteristik yapısı üzerinden bir insan hakları temellendirilmesine yönelmek mümkündür. Söz konusu karakteristik yapının farklı insan hakları temellendirmeleri mümkün olmakla birlikte burada üç aşamalı bir analiz üzerinden konuyu anlamaya çalışalım:

Birinci aşamada insanın varlıkla olan bilme ilişkisinin hangi dolayımda gerçekleştiği sorunsalı üzerinden bir temellendirmeye girişelim: İnsanın varlıkla olan bilme ilişkisi dolayımsız bir eylem olmaktan ziyade yerel, kültürel ve tarihsel örüntülerle oluşan bir süreçtir. Şu halde bireyin var olanla ilgili bilgisi doğrudan olmaktan çok, bilginin edinildiği yere ve zamana göre şekillenmiş bir edimdir. Bu sorunsal Francis Bacon'un idoller öğretisi bağlamında düşünüldüğünde her bireyin içinde yaşadığı toplum kendi mağarası olduğundan hakiki bilgiye ulaşmak için mağaradan çıkmak gerekmektedir. Konuşma diline de yansıyan toplumsal yargılar 
gerçeği olduğu gibi değil de, kısmen çarpıtarak yansıtan bulanık bir aynadan görmemize neden olmaktadır (Cevizci 2015: 451). Varlığın ve insanın bilgisine yaşadığımız toplumun dar ve kısmen çarpıtılmış ufkunda ulaştığımız düşünüldüğünde insan- varlık ilişkisinin çok sağlıklı bir biçimde oluşmadığı ortaya çıkmaktadır. Söz konusu süreçte zihnin, dil vasıtasıyla elde edilen münferit bilgileri genelleştirme eylemi içine girişeceği kaçınılmazdır. Dolayısıyla düşüncelerimiz yanlış, çarpık ve bulanık yargıların bir sonucu olarak genelleşmesi, zamanla hayata ve insanlara yönelecek olan bakış açımızı belirleyecektir. Diğer bir ifadeyle eğer göze takılan gözlük kirli ise varlığı kirli olarak görmemiz kaçınılmaz bir hal alacaktır. Bu durumda yerellik ve evrensel gerçeklik arasında bir çelişki durumu ile karşılaşılmaktadır. Ancak insan olarak yerel ve öznel olan değerleri önemseyip evrensel değerleri yadsımak ne derecede sağlıklı bir tutumdur?

Aslında yerelliği yansıtan gözlüğü çıkarıp evrenselin bilgisine ulaşmak istemeyen insanlar için fazla büyütülecek bir mesele yoktur. Çünkü onların zihin konforunu bozmak gibi bir sorunları söz konusu değildir. Kant'ın ifadesiyle insanların çoğu tembellik ve korkaklık nedeniyle hayatları boyunca kendi rızalarıyla aydınlanamamış olarak yaşarlar. Bununla birlikte o, varlığın genel geçer bilgisine ulaşabilmenin parolasından söz eder: "sapere auede! Aklını kendin kullanma cesaretini göster!” (Kant 2014: 315). Varlığın gerçek bilgisine ulaşabilme konusunda bir anahtar niteliği taşıyan bu parola aynı zamanda insan haklarını epistemolojik olarak temellendirmenin ipuçlarını da sunmaktadır. Öyle ki felsefe, yerel/tekil/kültürel olanı ussal karakteriyle epistemolojik bağlamda aşarak, evrensel boyutta düşünebilmeyi ve ortak insan kimliğinde buluşmayı sağlayabilecek bir yapıya sahiptir (Çotuksöken 2012: 58). Bunun nasıl sağlandığını yine Kant üzerinden örnekleyebiliriz: Ona göre düşünmek insanın kendi başına yapabileceği bir eylemmiş gibi olsa da, sağlıklı düşünmek başkalarının düşüncelerini de hesaba katmayı gerektirir. İnsanın kendi düşüncesini başkalarının düşünce ve eleştirileriyle sınaması onu dogmatik ve önyargılı olmaktan kurtarır (Kant 2008: 57). Buna göre doğru düşünmek ancak başkalarının bakış açıları incelenmeye açık olduğunda mümkün olabilecektir. Kant'a göre geniş bir zihniyetle düşünmek 
insanın kendi düşüncesini eğitmesini sağlar. Onun bu düşünceleri evrensel insan ve adalet anlayışının oluşmasında önemli rol oynayacaktır. Evreselliği ve ortak insanlık idealinde buluşmayı kendine şiar edinen Kant'ın hayatının son günlerinde söylediği şu söz ise onun düşüncelerini karakterize etmektedir: "İnsanlık duygusu beni henüz terk etmedi” (Yeşilçayır 2017: XVI). Dolayısıyla epistemolojik anlamda bilginin evrensel insana yönelip onu anlama çabası içinde olması insan haklarının aydınlatılması adına önemli bir adım olacaktır. Bununla birlikte insan haklarının evrenselliği konusu salt felsefenin icadı/uydurduğu bir teori midir? diye bir soru akıllara gelebilir. İkinci aşamadaki analizde bu soruya cevap bulmaya çalışalım:

Özellikle dikey ilişkilerin ve bu ilişkileri doğuran keyfiliğin yaşandığı yerlerde haklar bireylere bağışlanan/ihsan edilen bir şey olarak görülmektedir (Çotuksöken 2012: 40). Ancak hakların özel ya da tüzel bir kişilik tarafından bağışlanmadığı onların bizatihi insanın yalnızca insan olmasından dolayı sahip olduğu haklar olduğunun açığa çıkarılması/bilinmesi gerekmektedir. Nicolai Hartmann'a göre insan değerleri yaratan aktör değil, keşfeden kişidir. Buna göre insanın değeri varoluşsal ve evrensel olarak bizatihi mevcuttur (Kılıç 2007: 598). Önemli olan bu değerin anlaş1lıp uygulanmasıdır ki bu noktada felsefi kavrayışın ve epistemolojinin önemi kendisini hissettirmektedir. Buna göre insan hakları ifadesi insanın kendiliğinde olan değerinin insanlar tarafından keşfedilip formüle edilmiş biçimidir. Kuçuradi'nin ifadesine göre insan hakları düşünce tarihinde adım adım bilincine varılan haklardır (Kuçuradi 2016: 2). Dolayısıyla insan hakları batı kültürünün ya da başka bir kültürün ürünü olmayıp, insanlığın ortak düşünsel birikiminin bir sonucu olarak ortaya çıkmış, insanın yeryüzündeki bizatihi değerinin biçimsel bir form kazanmış halidir. Söz konusu değeri keşfediş sürecinde felsefi bakış açısının ve felsefi bilginin yadsınamaz bir önemi vardır. Şu halde insan haklarının etik temelli ve evrensel nitelikli olduğunun anlaşılması felsefi sorgulamanın/bilginin bir tezahürü olarak karşımıza çıkmaktadır. Bu bağlamda felsefe insan hakları ile ilgili nasıl farkındalık yaratabilir? diye başka bir soru ile karşılaşmak mümkündür. 
Üçüncü aşamada felsefe tarihinde etiğin kurucusu olarak bilinen Sokrates üzerinden örneklemeye başvurarak yukardaki soruya cevap bulmaya çalışalım: Onun diyaloglarında muhataplarına birtakım sorular sorarak bilgiyi doğurtmaya çalışması felsefesinin de temel karakterini oluşturmuştur. Platon'un Menon adlı diyaloğunda belirgin olarak karşımıza çıkan bilgiyi doğurtma metodu aynı zamanda Sokratik yöntem olarak da adlandırılmaktadır (Platon 2007: 281, 305). Bu yöntemiyle o sorduğu sorularla birine bir şey öğretmekten ziyade, onda zaten var olduğuna inandığı bilginin ortaya çıkmasına yardımcı olmak ister. Zekice hazırlanmış, mantıksal sorulardan oluşan bu diyaloglar ve Sokratik yöntem adı verilen teknik sonraları başta felsefe olmak üzere birçok alanda etkili olmuştur ve günümüzde eğitimde bir kuram olarak kabul edilmektedir. Dolayısıyla felsefenin temel karakteristiğini oluşturan diyalog, soru sorma, diyalektik, temellendirme, sentez gibi yöntemler akıl ve mantık dizgesi içinde bireyde zihni anlamda aydınlanmayı sağlayıcı özelliğe sahiptir. İnsan hakları düşünsel ve soyut özelliğinden dolayı felsefenin doğru bilgiyi ortaya çıkarmada başvurduğu mezkûr yöntemler bu kavramın aydınlatılmasına 1şık tutacak mahiyettedir. Bununla birlikte insan hakları konusunda zihinlerde yer alan muğlak düşüncelerin önüne geçilmesinde felsefi bilgi önemli rol oynayabilecektir.

Görebildiğimiz kadarıyla epistemoloji, insan haklarının bilgisel anlamda anlaşılmasında bir çok argüman sağlayıcı özelliğe sahiptir. Buraya kadar olan analizler çerçevesinde şöyle bir tez ileri sürebiliriz: İnsan aklı ve eliyle ortaya çıkan hak ihlallerini önlemek yine insanın aklıyla ve eliyle mümkündür. Bu bağlamda felsefenin analiz, sentez, sorgulama ve yeniden inşa etme gibi karakteristik özellikleri insan hakları ihlallerinin önlenmesine yönelik fikirlerin ortaya çıkmasına uygun bir temel olmaya oldukça elverişli bir yapıdadır. Dolayısıyla insan haklarının etik temellerinin ve hukuki boyutunun açıklanmasında epistemolojinin yadsınamayacak bir önemi vardır. Diğer taraftan insan haklarının anlaşılıp, uygulanmasına mani olan hususları felsefi bağlamda sorgulamamız yerinde bir tutum olacaktır. 


\section{İnsan Hakları İhlalleri Karşısında Felsefe}

Eğitim anlayışının insani anlayıştan uzak olması insan haklarının hayata geçmesini engelleyen temel faktörlerden biridir. Sözgelimi eğitimde dışlayıc1/ötekileştirici bir anlayışın benimsenmesi ülke içindeki farklı din/etnisiteler arasında nefret duygusuna ve kindarlığa dönüşebilmektedir. Buna göre belli bir etnik kökeni/dini/mezhebi temele alarak diğerlerini ötekileştiren bir eğitim anlayışını değiştirmek ve insani olana doğru evrilmek gerekmektedir. Yerkürede var olan tüm beşeriyetin, barış içinde yaşaması ancak insan merkezli bir eğitim anlayışı çerçevesinde sağlanabilir. Böyle bir dünya görüşünde dinsel, ulusal ve mahalli değerler yerine hümanist, evrensel değerler esastır (Ceylan 2010: 114). Söz konusu sorunsalı felsefenin eleştirel özelliği bağlamında da tahlil etmek mümkündür. Bu noktada din ve etnik kökene dayalı aidiyetler insanın asli özelliği midir? sorusunu irdelemek gerekmektedir.

Görebildiğimiz kadarıyla birçok durumda bireylerin sahip oldukları arı̂̂ özellikler olan etnik köken, milliyet, din ve mezhep gibi sıfatlar insan hayatının asli unsuru olarak kabul edilebilmektedir. Böylelikle bir gruba ait bireyin diğer gruptan daha üstün olduğu yargısına varılarak hak ihlallerine neden olunmaktadır. Sözgelimi bir etnisitenin, dinin ya da mezhebin insanın asli unsuru sayılması bu şekildeki hak ihlallerine yol açmaktadır. Hâlbuki insanın sabit, değişmez, kalıcı bir özünün olmadığı; her insanın değişebilir özellikler, nitelikler toplamından oluştuğu kavrayışından hareketle, hiçbir insansal özelliğin, niteliğin bir üstünlük nedeni olamayacağı, böylelikle insan haklarının grubun değil salt bireyin hakları olduğu savı ortaya çıkmaktadır (Çotuksöken 2012: 45). Öyle ki insan haklarının özünde insanın yalnızca insan olmasından kaynaklı doğal hakları mevcuttur. İnsanın kendisi bizâtihi bir değerdir ve sonradan oluşmuş hiçbir özellik onun insan olmaktan kaynaklı değerine zarar getirmemelidir. Buna göre insanın değeri farklı toplum ve kültürlerdeki insan anlayışlarının üstünde evrensel bir değer olarak düşünülmelidir. Dolayısıyla felsefi anlamda insanın değerini önemseyen bir eğitim anlayışının hayata geçirilmesi insan hakları bilincinin oluşturulması adına önemli bir adım olacaktır. 
Bununla birlikte felsefi düşünce önyargıların etkileme gücüne dikkat çekerek, insan haklarının korunmasında engel oluşturan tutumları bilinçli bir biçimde fark etmeyi sağlayan duyarlılık kazandırabilecek mahiyettedir. Kişiler arası ilişkilerde doğal karşılanan alışkanlıklar, kültürel yapılanmalar (kız çocuklarını okutmayıp erken yaşlarda evlendirmek gibi), değer yargılarının etkisiyle ortaya çıkan eylem biçimleri (cinsiyetçilik gibi) felsefi bakış açısı ve sorgulama ile incelikli bir düşünmenin, çözümlemenin sonucunda hak ihlallerinin nedeni ortaya koyulabilir. Dolayısıyla felsefi bilinç, bazı durumları bir sorun olarak görmemizi sağlar ve böyle bir görme biçiminin eksik olduğu ortamda insan haklarına ilişkin tutarlı bir yaklaşım oluşturulması mümkün değildir (Çotuksöken 2012: 53). Bunun yanında insan haklarının etik temellerini oluşturan insanın değerinin/onurunun bilgisi edinilmediği müddetçe söz konusu haklar konusunda bir zihin aydınlığından söz etmek pek mümkün görünmemektedir.

\section{Sonuç Yerine}

İnsan haklarının aydınlatılmasında felsefi bilginin önemini ele almaya çalıştığımız bu çalışmamızın son tahlilinde buraya kadar yaptığımız analizlerden bazı saptamalar ve bulgular elde etmeye çalışalım. Girişte insan hakları konusunda dünya genelinde yaşanan paradoksa değindik. Araştırmamız minvalinde yaşanan paradoksların temelinde bilgi eksikliğinin yattığı anlaşılmaktadır. Kaynağı ve içeriği aydınlatılmamış hakların insanlar tarafından ne anlama geldiği bilinemeyeceği gibi bu hakların nasıl kullanılacağına da karar verilemeyecektir. Bu durum da kaçınılmaz olarak bir takım açmazlarla karşılaşılmasına ve manipülasyonların yaşanmasına neden olacaktır. Bu çerçevede felsefi etik insan haklarının özü itibariyle aydınlatılmasını sağlayacak olan insanın değer ve onurunun bilgisinin anlaşılmasına 1şık tutmaktadır. Söz konusu bilgi ise insan haklarının aslında insan onurunun pratikte gerektirdikleri olduğuna işaret etmektedir. Buna göre insan haklarının kültürel normların üstünde evrensel etik normlar olarak anlaşılması gerekmektedir. 
Görebildiğimiz kadarıyla insan haklarının bilgisini elde etmek pozitif hukukun dar bağlamından ziyade etik temelli bir bakış açısını gerektirmektedir. Doğal hukukla ilintili olan söz konusu etik ilkelerin pozitif hukukun oluşumuna temel teşkil etmesi insan haklarının yasalaşması adına önem arz etmektedir. Buradan hareketle söz konusu doğal hukukun, pozitif hukukun oluşumuna örnek teşkil ettiği oranda insan hakları anlayışının ortaya çıktığı sonucuna ulaşmak mümkündür. Etik ve insan onuru bağlamında düşünüldügünde insan haklarının, bu hakların bilgisine sahip olan ya da olmayan herkesin temel hakları olduğu anlaşılmaktadır. Ancak buraya kadar olan analizler bize her bireyin temel haklarının bilgisini edindiği oranda insan haklarının farkına varabileceğini ve bu haklara salt insan olmaktan dolayı sahip olduğunun bilincinde olabileceğini göstermektedir. Çünkü insan ancak varlığının bilgisine sahip olduğu oranda insan haklarının bilincinde olacak, bu hakları hayatında işlevsel hale getirmek ve korumak isteyecektir. Varlığından haberdar olunmayan haklar konusunda insanların bilinçli olması beklenemeyeceği gibi, bu haklara sahip çıkması da pek mümkün olamayacaktır.

Temel insan haklarının neler olduğu ve içeriklerinin nasıl şekillendiği hususunda doğru bir bilgiye sahip olmak için felsefenin iki temel alanı olan aksiyoloji ve epistemolojinin önemi yadsınamaz. Buna göre insan hakları özü itibariyle değere dayalı hakları içermektedir ve bu değerin açığa çıkarılıp anlaşılmasında felsefi bilgi yadsınamaz bir öneme sahiptir. Diğer taraftan epistemolojinin kendine özgü temellendirmeleri insan haklarının aydınlatılmasına 1şık tutmaktadır. Buna göre bilginin evrensel insana yönelip onu anlamayı amaçlaması insan haklarının bilgisel aydınlatılması bağlamında önemlidir. Şu halde insan haklarının birilerinin türettiği bir fikir olmayıp, insanın kendi özünü keşfedişinin bir bilgisi olduğunun ortaya konması epistemolojik bir sorgulama ile anlaşlabilecek bir tutumdur. Bilgiyi doğurtmayı hedefleyen Sokratik yöntem öğretmekten ziyade var olan bilgiyi açığa çıkarmayı hedefleyerek bu türden bir bilginin peşindeydi. Araştırmamızda yer verdiğimiz analizler çerçevesinde insan haklarının aydınlatılmasına yönelik ilgili şu tespitlere ulaşmamız mümkündür: 
İnsan hakları pozitif hukukun sınırlı muhtevasından önce etik bağlamda anlaşılması ve insan onuru temelinde aydınlatılması gereken bir kavramdır. Hukuk ve bunu işlevsel hale getirecek siyasetin insan haklarının etik muhtevasının uygulanacağı bir alan olarak görülmesi/belirlenmesi gerekmektedir. Felsefe, sorgulayan/eleştiren ve kavramların özüne nüfuz etmeyi hedefleyen karakteri nedeniyle, söz konusu süreçte başvurulacak temel bir araçtır. Bu bağlamda insan haklarının hukuk ve siyaset gibi alanlardan önce yalnızca insan olmaktan kaynaklanan temel haklar olduğunun anlaşılmasında felsefenin rolü yadsınmamalıdır. Bununla birlikte insan haklarının bilgisine ulaşmada ve bu temel haklar konusunda aydınlanmada eğitimin yadsınamaz bir önemi olduğu anlaşılmaktadır. Ancak haklar konusunda eğitim almış bireyler insan olarak haklarının bilgisi konusunda bilinçlenebilirler. Diğer taraftan yaşanan insan hakları ihlallerine bakıldığında mevcut insan hakları eğitiminin yapı ve muhteva olarak yetersiz olduğunu iddia etmemiz mümkündür. Felsefenin eleştirel, sorgulayıcı, analitik ve sentezci özelliklerinin insan hakları eğitimine kazandırılması bu eğitimin verimliliğini artırmakla birlikte bu tutum insan hakları aydınlatılması adına da önemli bir kazanım olacaktır. Bununla birlikte okullarda insan hakları adı altında dersler vermekten ziyade insan hakları bilincini derslerin temel karakteri haline getirmek haklar adına daha etkili farkındalık sağlayacaktır. Bu bağlamda eğitimi bir meslek kazanma süreci olarak düşünmeden önce bir insan olma/insanlaşma süreci olarak düşünmek ve bu anlayışı hayata geçirmeye çalışmak gerekmektedir. İnsan hakları eğitimi ile bağlantılı olarak okullarda barış eğitimini de uygulamaya geçirmek bu eğitimi destekleyici olacaktır. Bütün bunlar icra edilirken kültürel/yerel/etnik değerleri insanın değerinin üstüne çıkarmamaya özen göstermek insan haklarının temeli gözden kaçırmamak adına önem arz etmektedir. İnsan haklarının bilgisi bağlamında insan haklarının bilgisine ulaşmak ihlalleri önlemek için yeterli midir? diye bir soru yöneltmiştik. Kanaatimize göre insan hakları konusunda bilgilenmek, ihlallerin önlenmesinde yeterli olmasa da, hakların anlaşılması adına önemli bir adımdır. Bu adım, insan hakları hususunda bilinçlenme ve duyarlı olmak için gerekli zemini hazırlamaktadır. İnsan hakları hususunda bilinçlenmenin yolu da şüphesiz doğru 
uygulanacak bir insan hakları eğitiminden geçmektedir. Dolayısıyla insan haklarının bir yaşam biçime dönüşebilmesi ve korunabilmesi öncelikle hakların bilinmesine bağlıdır.

Felsefi bilginin insan haklarının özü itibariyle anlaşılmasında sağlayacağı kazanımların yanında söz konusu haklar konusundaki bilinçlenme ile bu hakların korunması adına da önemli derecede bir yol haritası sunacağını iddia etmemiz mümkündür. Şu halde insan haklarının etik bağlamda anlaşılabilecek temelleri olduğunu söylerken aynı zamanda bu hakları korumanın siyasal olmaktan önce etik bir sorunsal olduğunu da ifade etmemiz gerekmektedir. Öyle ki insani değerler zaman zaman vatandaşlık uğruna, etnik benlik uğruna, din ve mezhep uğruna görmezden gelinebilmektedir. Hatta bu ihlallere demokrasi kisvesinin giydirildi kimi durumlar bile yaşanmaktadır. İnsanlık durumlarındaki bu ve buna benzer olumsuzluklara bakıldığında insan hakları bağlamında evrenseli hedefleyen etik temelli aydınlanmanın elzem olduğu anlaşılmaktadır. Dolayısıyla insan hakları konusunda küresel anlamda yaşanan paradoksal durum ve diğer insan hakları sorunlarının anlaşılmasında ve sorunların temellerinin irdelenmesinde felsefi bakış açısının vazgeçilmez bir öneme sahip olduğunu anlamaktayız. $\mathrm{Bu}$ minvalde insan haklarının bilgisel anlamda aydınlatılmasında felsefenin etik, hukuk felsefesi ve epistemoloji gibi temel disiplinlerinin başat rol oynayabileceği gözden kaçırılmaması gerekmektedir. 


\section{KAYNAKÇA}

BEITZT, Charles R. (2013). "Human Dignity in the Theory of Human Rights: Nothing But a Phrase?”, Philosophy \& Public Affairs 41(3): 259-290.

CEYLAN, Yasin (2010). "Yirmibirinci Yüzyılda Eğitim Felsefesi Nasıl Olmalıdır?", Uluslararası Eğitim Felsefesi Kongresi Bildirileri, ss. 114-116, Ankara: Eğitim Bir-Sen.

CEVİZCI, Ahmet (2014a). Etik-Ahlak Felsefesi, İstanbul: Say Yayınlar1.

CEVİZĊ, Ahmet (2014b). Felsefe Sözlüğü, 4. Baskı, İstanbul: Say Yayınları.

CEVİCI, Ahmet (2015) Felsefe Tarihi, 6. Bask1, İstanbul: Say Yayınları.

ÇOTUKSÖKEN, Betül (2012). Insan Hakları ve Felsefe, İstanbul: Papatya Yayınc1lık.

DAVRAN, Zeynep (1999). "İnsan Haklarının Düşünsel Temelleri”, İnsan Haklarının Gelişimi, ss. 19-25, Ankara: Türkiye Bilimler Akademisi Yayınları.

DW (2008). "Dünya insan haklarını hiçe sayıyor" Erişim Tarihi: 12.07.2018, (https://www.dw.com/tr/d\%C3\%BCnya-insan-haklar\%C4\%B1n\%C4\%B1hi\%C3\%A7e-say\%C4\%B1yor/a-3365265).

GERLACH, Sebastian (2010). Innere Konfliktregelungsmechanismen der Afrikanischen Union vor dem Hintergrund der entsprechenden Bestimmungen der Europäischen Union, Frankfurt am Main: Peter Lang Verlag. Yayınları.

GÜLMEZ, Mesut (2001). Insan Haklarl ve Demokrasi Eğitimi, Ankara: Todaie

HABERMAS, Jürgen (2010). "Das Konzept der Menschenwürde und die realistische Utopie der Menschenrechte", Deutsche Zeitschrift für Philosophie, Akademie Verlag, 58(3): 343-357.

KANT, Immanuel (2014). “Aydınlanma Nedir? Sorusuna Yanıt”, Immanuel Kant Seçilmiş Yazılar, çev. Nejat Bozkurt, ss. 313-325, 4. Baskı, Ankara: Sentez Yayınc1lik.

KANT, Immanuel (2008). "Was heisst: Sich im Denken orientieren?" (1786), Zum ewigen Frieden und andere Schriften, ss. 44-60, Frankfurt am Main: Fischer Verlag.

KEYMAN, Selahattin (1998). "Tabii Hukuk Doktrininin Epistemolojik Tahlili”, Ankara Üniversitesi Hukuk Fakültesi Dergisi, 47(1-4): 17-36.

KILIÇ, Muharrem (2007). "Etik-Hukuksal Değerlerin Nesnelliğinin / Evrenselliğinin Temellendirilmesi Bağlamında İnsan Hakları Eğitimi”, Değerler ve Ĕ̆itimi Uluslararası Sempozyumu Bildiriler, ss. 595-612, İstanbul: Dem Yayınları. 
KILIÇ, Yavuz (2015). “Kant'1n Etik Görüşünde Değerli Eylemin Olanağı”, Pamukkale Üniversitesi Sosyal Bilimler Enstitüsü Dergisi, 22: 93-100.

KUÇURADİ, İoanna. (2003). "Etik ve Etikler", Türkiye Mühendislik Haberleri, 423(1): 7-9.

KUÇURADİ, İoanna (2016). Insan Hakları: Kavramları ve Sorunları, 3. Bask1, Ankara: Türkiye Felsefe Kurumu.

MANSTETTEN, Reiner (2005). "Freiheit, Heil und Politik, Von Aristoteles über Las Casas zur Idee der Menschenrechte", Wege zur Politischen Philosophie, ss. 101-118, Hrsg. Gabriele von Sivers und Ulrich Diehl, Würzburg: Königshausen und Neumann.

ÖĞÜTÇÜ, Muhlis (2005). "Doğal Hukuk Ve Pozitif Hukuk Işığında İnsan Hakları Alanındaki Bazı Kavramlar", Dokuz Eylül Üniversitesi Hukuk Fakültesi Dergisi, 7: 555-615.

PLATON (2007). "Menon”, çev. Tuna Poyraz, Toplu Diyaloglar - I, ss. 277315, Ankara: Eos Yayınları.

SANDEL, Michael J. (2013). Adalet: Yapılması gereken Doğru Şey Nedir?, çev. Mehmet Kocaoğlu, Ankara: BigBang Yayınları.

SAVCI, Bahri (2016). "Yaşam Hakkı”, İnsan Haklarının Felsefi Temelleri, ss. 83-92, yay. haz. İoanna Kuçuradi, Ankara: TFK.

SCHMEER, Elis (2010). Responsibility to Protect und Wandel von Souveränität, Berlin: BWV Verlag.

SEN, Amartya (2004). "Elements of the Theory of Human Rights", Philosophy and Public Affairs, 32 (4): 328-332.

SIRLESCHTOV, A., MONATH H., WORATSCHKA R., (2018). "Seehofer bedauert Suizid von abgeschobenem Afghanen", Erişim Tarihi: 13.07.2018, (https://www.tagesspiegel.de/politik/asylpolitik-seehofer-bedauert-suizid-vonabgeschobenem-afghanen/22789716.html).

TEZCAN, Durmuş, Mustafa Ruhan ERDEM, Oğuz SANCAKTAR, Rifat Murat ÖNOK (2011). Insan Hakları El Kitabı, 4. Baskı, Ankara: Seçkin Yayıncılık.

YEŞİLÇAYIR, Celal (2016). "Sığınmacılar Hakkındaki Ön Kabulleri Belirleyen Etmenler Üzerine Eleştirel Bir Değerlendirme”, Kutadgubilig Felsefe-Bilim Araştırmaları, 32: 121-138.

YEŞİLÇAYIR, Celal (2017). Ebedi Barış Pax Romadan Birleşmiş Milletlere, İstanbul: Tezkire Yayıncılık. 